\title{
Pengaruh Penerapan Standar Akuntansi Zakat (Psak 109), Shariah Compliance, Transparansi Dan Kompetensi Sumber Daya Manusia (Amil) Terhadap Pengelolaan Dana Zakat (Studi kasus Lembaga Pengelola Dana Zakat Kabupaten Pemalang)
}

\author{
Nur Imamah ${ }^{1}$ \\ Imamah904@gmail.com
}

Jurusan Akuntansi Syariah, Fakultas Ekonomi Dan Bisnis Islam, Universitas Islam Negeri Walisongo Semarang

\begin{abstract}
This study aims to train whether there is an effect of zakat reporting (PSAK 109), sharia compliance, transparency and human resource competence on the management of zakat funds. The object of this research is zakat management institutions in Pemalang district.

The type used in this research is quantitative. The data used are primary data by distributing questionnaires to zakat institutions in Pemalang Regency including Baznas, Laz Al-Ikhsan, Laziz MU, Laziz Nu, and BBI. There were 36 questionnaires that were collected and could be processed. Testing in research using multiple linear analysis method with SPSS program.

The results of this study indicate that the application of accounting has a positive and significant effect on the management of zakat funds in Pemalang, sharia compliance has a positive and significant effect on the management of zakat funds in Pemalang, transparency has a positive and significant effect on the management of zakat funds in Pemalang, human resource competence (amil) has a positive and significant effect on the management of zakat funds in Pemalang.

So it can show the results of this research are that zakat institutions must be able to improve and maintain aspects of the application of sharia accounting, sharia compliance, transparency and human resource competence (amil) in order to gain the trust of the public to flow zakat, infaq / shadaqoh through institutions to maximize in management in order to create an equity and welfare for the general public.
\end{abstract}

Keywords: implementation of sharia accounting; sharia compliance; transparency and human resource competence (amil).

\begin{abstract}
Abstrak
Penelitian ini bertujuan untuk menguji apakah terdapat pengaruh penerapan akuntansi zakat (PSAK 109), shariah compliance,transparansi dan kompetensi sumber daya manusia terhadap pengelolaan dana zakat. Objek penelitian ini ialah lembaga pengelola zakat yang terdapat di kabupaten Pemalang. Jenis data yang digunakan dalam penelitian ini adalah kuantitatif. Data yang digunakan berupa data primer dengan menyebar kuisioner ke lembaga zakat di Kabupaten Pemalang meliputi Baznas,Laz AlIkhsan,Laziz MU,Laziz Nu, dan BBI. Kuisioner yang terkumpul dan dapat diolah sebanyak 36 buah dari 41 buah. Pengujian dalam penelitian ini menggunakan metode analisis linier berganda dengan program SPSS.

Hasil dari penelitian ini menunjukan bahwa penerapan akuntansi syariah berpengaruh positif dan signifikan terhadap pengelolaan dana zakat di Pemalang,shariah compliance berpengaruh positif dan signifikan terhadap pengelolaan dana zakat di Pemalang,transparansi berpengaruh positif dan signifikan terhadap pengelolaan dana zakat di Pemalang,kompetensi sumber daya manusia (amil) berpengaruh positif dan signifikan terhadap pengelolaan dana zakat di Pemalang.

Jadi dapat disimpulkan hasil dari penelitian ini ialah lembaga zakat harus dapat meningkatkan dan mempertahankan aspek penerapan akuntansi syariah,shariah compliance,transparansi dan kompetensi sumber daya manusia (amil) agar dapat memperoleh kepercayaan dari masyarakat untuk menyalurkan zakat,infak/shadaqoh melalui lembaga untuk memaksimalkan dalam pengelolaan agar terciptanya sebuah pemerataan dan kesejahteraan bagi masyarakat umum.
\end{abstract}


Kata Kunci : penerapan akuntansi syariah; shariah compliance; transparansi dan kompetensi sumber daya manusia (amil).

\section{Pendahuluan}

Zakat,infak/shadaqoh apabila dikembangkan di Indonesia akan menjadi salah satu instrumen pemerataan pendapatan yang berguna untuk mengurangi tingkat kemiskinan sebagai akibat dari ketimpangan pendapatan.Sehingga orang yang mampu atau hartanya sudah mencapai nisab dapat membayarkannya lewat lembaga pengelola zakat atau yang mempunyai harta lebih dan ingin memberikan sebagian hartanya untuk orang lain tanpa maksud untuk memiskinkan orang kaya (Apriliani, 2017).

Dengan adanya Zakat, Infak dan Shadaqoh tersebut tentu harus diberi wadah yang dapat dipercaya oleh masyarakat untuk mengelola dana tersebut. Dengan adanya masalah tersebut pemerintah menerbitkan Undang-Undang No.23 Tahun 2011 tentang pengelolaan zakat, yang mengatur Organisasi Pengelola Zakat (OPZ) yang boleh beroperasi di Indonesia yaitu Badan Amil Zakat (BAZ) dan Lembaga Amil Zakat (LAZ) (Sanjaya, I , K, 2019).

Akuntansi zakat mempunyai arti salah suatu bidang ilmu akuntansi yang diperuntukan untuk menentukan dan menilai asset wajib zakat, menimbang kadarnya (volume), dan pendistribusian hasil untuk mustahik berdasarkan aturan dalam syariah Islam (Umah, 2011).

Transparansi memiliki arti sebuah keterusterangan secara universal serta memberikan ruang bagi partisipan aktif dari berbagai kalangan masyarakat dalam kaitannya dengan proses pengelolaan sumber daya publik (Hajar, 2017).

Kepatuhan syariah atau Shariah Compliance merupakan prinsip-prinsip syariah yang harus ada pada pengelolaan zakat.Karena bukan hanya saja kepercayaan Muzakki terhadap Amil zakat melainkan menyangkut dengan nilai moral dan juga tanggung jawab terhadap Allah SWT (Lusi \& Usnan, 2017a).

Kompetensi merupakan kemampuan seseorang dalam menghasilkan sesuatu yang memuaskan ditempat kerja,dengan cara mengaplikasikan kemampuan dan wawasan tersebut pada keadaan baru serta digunakan untuk meningkatkan utilitas yang telah disepakati (Wijayanti \& Handayani, 2017).

Dengan melihat populasi masyarakat muslim di Indonesia, menurut sumber Baznas dalam Sari (2019) memiliki Potensi Zakat mecapai Rp.217 Triliun sebenarnya bisa membantu mengurangi angka kemiskinan di Indonesia. Namun berbeda dengan kenyataan, bahwa ditahun 2016 Baznas hanya berhasil mengumpulkan zakat sebesar Rp.5,01 Triliun dan ditahun 2017 sebesar Rp.6 Triliun meskipun ada kenaikan sedikit itu masih jauh dari target karena Baznas memiliki target untuk penerimaan zakat sebesar Rp. 8,77 Triliun,tentu ini masih berbeda dengan potensi yang dimiliki oleh Indonesia,sehingga terjadi gap antara potensi dengan realisasinya.

Sedangkan di Kabupaten Pemalang menurut Taufik Rahman selaku ketua KanKemenag Kabupaten Pemalang pada acara pembinaan lembaga Amil zakat (13/10) menuturkan bahwasanya apabila seluruh wajib zakat mengeluarkan zakatnya,kurang lebih akan memperoleh sebesar 10 Milyar rupiah.Faktanya,saat ini hanya mampu mengumpulkan zakat sebesar 1,2 Milyar rupiah dalam satu tahun saja (Potensi Zakat Kabupaten Pemalang Sangat Besar 2, 2015). Tentu angka ini masih sangat jauh dari potensi yang dimiliki.

Dengan adanya ketimpangan antara pendapatan dengan realisasi yang diperoleh tentu perlu adanya kajian dalam kaitannya dengan pengelolaan dana zakat,karena sebuah pengelolaan dana zakat akan dikatakan efektif dan efisien apabila berjalan sesuai alurnya yaitu dimulai dari proses pengumpulan,pendristribusian dan pendayagunaan dana zakat. Tanpa diterapkannya akuntansi zakat,peraturan syariah,transparansi dan kompetensi Amil akan timbul rasa ketidak percayaan masyarakat terhadap lembaga pengelolaa dana zakat yang akan berakibat pada penurunan efektifitas dan efisiensi pengelolaan dana zakat.Untuk itu tujuan dari penelitian ini ialah untuk mengkaji pengaruh penerapan standar akuntansi zakat (PSAK 109), shariah compliance, transparansi dan kompetensi (ami) terhadap pengelolaan dana zakat. 


\section{Tinjauan Pustaka}

\subsection{Zakat, Infak dan Shadaqoh}

Zakat berasal dari kata zaka yang artinya suci,baik,tumbuh atau berkembang. Sedangkan berdasarkan istilah zakat merupakan nama sebagian harta yang telah mencapai syarat tertentu yang telah Allah wajbkan untuk diberikan kepada yang berhak menerimanya tentu dengan syarat-syarat tertentu pula. Istilah ini tentu saling berkaitan dimana ketika zakat telah dikeluarkan harta tersebut akan kembali suci.tumbuh dan berkembang (Budi, 2017).

Tak hanya itu zakat memiliki arti secara harfiah yaitu pembersihan diri sebagai akibat dari kewajiban yang telah dibayarkan.Sedangkan menurut fikih zakat ialah sejumlah harta yang dikeluarkan untuk orang tertentu dengan syarat tertentu pula (Afendi, 2018).

Zakat sendiri disebut dalam Al-qur'an sebanyak 32 kali,salah satunya terdapat di Al-Quran surah Al-Baqarah ayat 43:

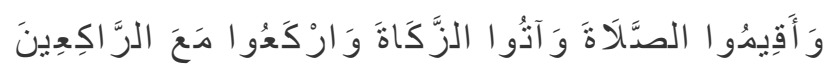

Artinya : " dan dirikanlah shalat, tunaikanlah zakat dan ruku'lah beserta orang-orang yang ruku” (JavanLabs, 2020).

Terdapat delapan jenis golongan yang boleh menerima zakat:
a. Fakir
b. Miskin
c. Amil
d. Muallaf
e. Budak
f. Gharimin
g. Fii Sabilillah
h. Ibnu Sabil

Sedangkan Infak dan shadaqah bukan merupakan sebuah kewajiban.Yang bersifat suka rela tidak terikan serta tidak mempunyai syarat-syarat tertentu baik dari segi waktu,jumlah maupun kadarnya.

\subsection{Akuntansi Zakat Infak/Shadaqoh (PSAK 109)}

Pada tangal 18 oktober 2005 disahkannya PSAK 109 berisi aturan mengenai zakat infaq dan shadaqah yang dibentuk oleh komite akuntansi syariah (KAS) yang tidak terlepas dari peran PSAK 59. Desakan kebutuhan akan berkembangkan lembaga keuangan syariah yang menuntut untuk menyempurnakan pengelolaan zakat infaq shadaqah pada lembaga keuangan Syariah, beberapa lembaga keuangan syariah yang memiliki wewenang dalam pengelolaan ZIS seperti Badan Amil Zakat (BAZ), Lembaga Amil Zakat ( LAZ), dan Unit pengelolaan zakat (UPZ).PSAK 109 memiliki tujuan untuk melakukan pengakuan,pengukuran,penyajian dan pengungkapan terkait dengan transasksi zakat infaq dan shadaqah (Aprilia, 2017).

\subsection{Shariah Compliance}

Kepatuhan berasal dari kata patuh yang mempunyai makna taat,yang artinya taat pada aturan yang dibuat (Rosa, 2018). Sedangkan Syariah adalah hukum-hukum dan aturan Allah yang disyariatkan untuk hambanya untuk diikuti dan hubungan antar sesama manusia (Islami, 2017).

Dana zakat yang telah dikelola akan diaudit secara dua tahap;audit syariah dilakukan oleh kementrian Agama sedangkan audit keuangan dilakukan oleh akuntan publik,yang kemudian akan dilaporkan kepada BAZNAS.Shariah compliance diaudit syariah menggunakan standar Accounting and auditing Organisation of Islamic Finansial Institusion (AAOIFI) ysng mempunyai tugas untuk mengawasi kepatuhan syariah yang dilakukan oleh lembaga keuangan (Lusi \& Usnan, 2017b). Dengan adanya audit ini dapat melihat seberapa jauh sebuah lembaga taat akan aturan syariah yang telah dibuat,karena Semakin tinggi kepatuhan syariah pada suatu organisasi maka akan menciptakan loyalitas steakholoder yang kuat dan yang akan berpengaruh terhadap kinerja keuangan organisasi (Sanjaya, I, K, 2019). 


\subsection{Transparansi}

Transparansi adalah pemberian informasi kepada masyarakat dengan alas an masyarakat harus tau kemana saja aliran dana yang telah dibayarkan (Nasim \& Romdhon, 2014). Transparansi sangat penting terutama dalam hal pengelolaan dana zakat,dimana kepercayaamn masyarakat terletak pada transparansinya laporan keuangan sebuah lembaga atau organsasi.Ketika Muzakki melihat adanya transparansi dana zakat secara otomatis akan meningkatkan kepercayaan Muzzaki terhadap lembaga zakat dan akan beralih dalam pembayarannya yang semula masih bersifat tradisional menuju lembaga zakat. Lembaga zakat dapat melakukan transparansi dengan cara memberikan informasi melalui media elektronik,sosialisasi dan media cetak (Lusi \& Usnan, 2017b).

\subsection{Kompetensi Sumber Daya Manusia (Amil)}

Kompetensi sumber daya manusia adalah kemampuan seseorang dalam bekerja terhadap organisasi dengan menjalankan sesuai dengan fungsi-fungsi dan kewenangan agar sebuah tujuan organisasi dapat berjalan dengan efisien dan efektif (Apriliani, 2017).

Keberhasilan suatu organisasi sangat ditentukan oleh kompetensi sumber daya manusia yang dimiliki oleh organisasi yang dimana Amil dituntut untuk melakukan pelayanan yang terbaik agar masyarakat memiliki pandangan yang baik terhadap lembaga zakat tersbut dan secara perlahan akan berminat untuk menyalurkannya kepada lembaga zakat (Hardyansyah, 2016).

\subsection{Pengelolaan Dana Zakat}

Pengelolaan zakat merupakan sebuah kegiatan yang meliputi perencanaan, pelaksanaan, pengumpulan, pendsitribusian dan pendayagunaan dana zakat.Lembaga yang bertugas mengelola zakat di Indonesia terbagi menjadi dua yaitu Badan Amil zakat (BAZ) dan lembaga Amil Zakat (LAZ).Terdapat dua aspek dalam pengelolaan dana zakat yaitu:

a. Pengumpulan

Dalam pengumpulan dana zakat kegiatan yang dilakukan diawal yaotu dengan perencanaan berupa Budgetting dan pengumpulan data Muzakki dan Mustakhik yang akan memperoleh dana tersebut.Yang kemudian dilanjutkan dengan penyusunan struktur peletakan SDM yang tepat,pemilihan system pelayanan yang memadai,sosialisai, pengawasan syariah,menajemen, dan keuangan oprasional pengelolaan zakat. Tanpa adanya sebuah perencanaan yang matang tidak mungkin sebuah organisasi akan mencapai tujuan.

b. Pendistribusian dan Pendayagunaan

Dalam melakukan pendistribusian tentu lembaga zakat tentu harus sesuai prinsip syariah dan menggunakan skala prioritas terhadap 8 golongan penerima zakat dalam hal pemerataan,keadilan dan kewilayahan. Dalam penyaluran dana Baznas juga memberikan pendayagunaan dana zakat sesuai dengan kebutuhan yang diperlukan dimana menggunakan konsep menghargai dan memberdayakan (Lusi \& Usnan, 2017b).

\subsection{Penelitian Terdahulu dan Pengembangan Hipotesis}

\section{Pengaruh penerapan standar akuntansi Zakat (PSAK 109) terhadap pengelolaan dana zakat}

Penerapan standar akuntansi pada suatu lembaga atau organisasi sangat penting,sama halnya dengan lembaga pengelola zakat,penerapan akuntansi zakat ini tentu sangat dibutuhkan karna berkaitan dengan pertanggungjawaban kepada Publik atas hasil dari pencapaian suatu kinerja.Akuntansi zakat empunyai tujuan yaitu sebagai bentuk pelaporan kepada publik terutama pemerintah dan muzakki agar diketahui bahwa pengelolaan zakat sudah dilakukan dengan benar (Sari, 2019).

Dalam penelitian yang dilakukan oleh Apriliani (2017) mengungkapkan bahwa penerapan standar akuntansi zakat (PSAK 109) berpengaruh positif terhadap kualitas laporan keuangan LAZ dikota Semarang.Hal ini menunjukan bahwa semakin baik pemahaman akan aturan akuntansi zakat yang dapat dipertanggung jawabkan maka akan memberikan sebuah dasar yang baik untuk pengelolaan dana zakat Selain itu semakin baik penerapan dan pelaksanaan akuntansi zakat akan meningkatkan kualitas laporan keuangan yang kemudian akan berpengaruh dengan teraturnya pengelolaan dana zakat. 


\section{H1 : Penerapan akuntansi zakat (PSAK 109) berpengaruh positif terhadap pengelolaan dana zakat}

\section{Pengaruh Shariah Compliance terhadap pengelolaan dana zakat}

Shariah compliance dapat didefinisikan salah satu bagian penting dalam pengelolaan dana zakat,didalamnya terdapat prinsip-prinsip syariah yang berlandaskan pada hukum Allah SWT dalam mengelola dana zakat. Karna pada pelaksanaan pengelolaan dana zakat bukan hanya berhunungan dengan kepercayaan muzakki terhadap amil saja,melainkan ada hal yang paling penting yaitu berkaitan dengan nilai moral dan pertanggung jawaban amil terhadap Allah SWT sebagai pemilik syariah (Lusi \& Usnan, 2017a).

Berdasarkan penelitian (Ika Sanjaya 2019) berhasil mengungkapkan hasil yang menyatakan jika shariah compliance berpengaruh positif terhadap pengelolaan dana zakat diKota Pekan Baru. Pemahaman yang baik dan benar mengenai shariah Compliance akan memberikan panduan bagi amil dalam mengelola dana zakat. Selain itu, shariah compliance berguna untuk meminimalisir adanya penyalahgunaan dana zakat. Serta adanya pemahaman mengenai konsep zakat.

\section{H2 : Shariah Compliance berpengaruh terhadap pengelolaan dana zakat}

\section{Pengaruh Transparansi terhadap pengelolaan dana zakat}

Transparansi ialah sebuah keterbukaan pemerintah atau organisasi terhadap suatu infomasi pengelolaan dananya dialirkan yang harus diketahui oleh masyarakat umum yang membutuhkan. Transparansi berlandaskan pada kebebasan dalam mendapatkan informasi yang dibutuhkan oleh khalayak umum yang dapat diperoleh secara langsung.

Berdasarkan penelitian yang pernah dilakukan oleh Lusi \& Usnan (2017b) mengungkapkan jikalau transparansi berpengaruh positif terhadap pengelolaan dana zakat di organisasi pengelola zakat Kabupaten Sukoharjo. Ini menunjukan semakin baik transparansi maka semakin baik pula pengelola dana zakat,dan semakin tidak transparansi suatu lembaga atau organisasi semakin buruk pula pengelolaan dana zakatnya.Tak hanya itu,transparansi juga sangat mempengaruhi tingkat kepercayaan masyarakat terhadap pengelolaan dana zakat,sehingga terjadi hubungan semakin tinggi keterbukaa sebuah lembaga semakin tinggi pula tingkat kepercayaan masyarakat terhadap lembaga pengelola zakat.

\section{H3 : Transparansi berpengaruh terhadap pengelolaan dana zakat}

\section{Pengaruh Kompetensi Sumber daya Manusia (AMIL) Terhadap Pengelolaan Dana Zakat}

Terdapat dua faktor terpenting dalam kompetensi SDM yaitu pendidikan dan pengalaman kerja. Dalam dunia pendidikan berisikan pemahaman mengenai pengetahuan dan pemahaman kemampuan mental mengenai pemecahan masalah. Prilaku yang tepat dalam pengambilan keputusan akan sangat berpengaruh terhadap tujuan sebuah organisasi.Selain itu pendidikan juga berpengaruh terhadap arah sikap atau prilaku seseorang didalam organsasi. Sedangkan untuk pengalaman kerja juga dibutuhkan untuk melihat jenis pekerjaan yang telah dilakukan dan membuka peluang bagi seseorang untuk mengerjakan pekerjaan yang lebih baik. Biasanya semakin luas pengalaman seseorang dalam bekerja maka semakin terampil pula dalam melakukan pekerjaan.

Menurut penelitian yang dilakukan oleh Hardyansyah (2016) mengungkapkan bahwa Kompetensi sumber daya manusia berpengaruh positif terhadap kualitas laporan keuangan pemerintah daerah,hal ini menunjukan bahwa timbul kesadaran responden bahwa sumber daya manusia membuktikan bahwasanya amil yang memiliki kemampuan dibidangnya dapat menyelesaikan dengan maksimal maka akan berpengaruh terhadap kualitas laporan yang dihasilkan. Sehingga dapat disimpulkan semakin baik kompetensi seorang amil dalam melakukan tugasnya,maka semakin baik pula pengelolaan keuangan.

H4 : Kompetensi sumber daya manusia berpengaruh positif terhadap pengelolaan dana zakat 


\subsection{Model Penelitian}

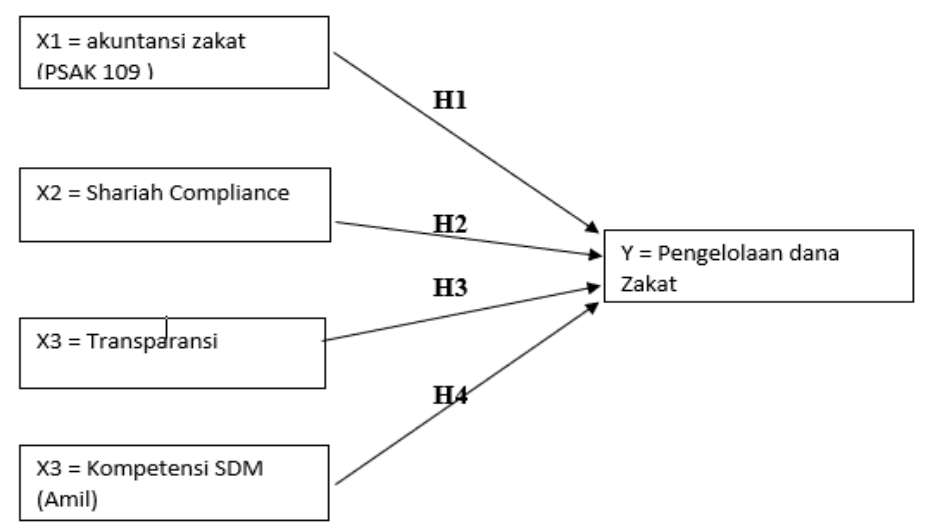

Gambar 1. Model penelitian

\section{Metode Penelitian}

\subsection{Populasi dan sampel}

Populasi dari penelitian ini ialah lembaga pengelola dana zakat di Kabupaten Pemalang yang berjumlah sebanyak lima lembaga.

Dalam penelitian ini menggunakan teknik Simpel random sampling yang merupakan bagian dari Probability Sampling yang dalam teknik ini cara pengambilan sempel dalam populasi dilakukan secara acak tanpa memperhatikan strata dalam populasi tersebut.Untuk itu sempel harus benar-benar mewakili.Dalam penelitian ini menggunakan 36 sampel kepada amil yang bekerja di lembaga pengelola dana zakat di Kabupaten pemalang.

\subsection{Definisi Operasional dan Pengukuran Variabel}

\section{Akuntansi Zakat (X1)}

Indikator yang digunakan dalam penelitian ini ialah pengukuran dan penerimaan ZIS, pengukuran asset, penyajian ZIS.Instrumen yang digunakan untuk akuntansi zakat dengan mengajukan pertanyaan pada kuisioner. Setiap item diukur dengan menggunakan skala linkert mulai dari 5 sangat setuju dan 1 sangat tidak setuju.

\section{Shariah Compliance (X2)}

Indikator yang digunakan dalam penelitian ini ialah prinsip amanah,profesional dan bertanggung jawab, bersifat qira'ah dan ilah, pengawasan. Instrumen yang digunakan untuk Shariah compliance dengan mengajukan pertanyaan pada kuisioner. Setiap item diukur dengan menggunakan skala linkert mulai dari 5 sangat setuju dan 1 sangat tidak setuju.

\section{Transparansi (X3)}

Indikator yang digunakan dalam penelitian ini ialah periodik dan tepat waktu, kemudahan akses informasi, publikasi media massa, penggauditan. Instrumen yang digunakan untuk Transparansi dengan mengajukan pertanyaan pada kuisioner. Setiap item diukur dengan menggunakan skala linkert mulai dari 5 sangat setuju dan 1 sangat tidak setuju.

\section{Kompetensi SDM (X4)}

Indikator yang digunakan dalam penelitian ini ialah peraturan perundang-undangan,standar yang berlaku,kode etik amil zakat Indonesia. Instrumen yang digunakan untuk Kompetensi SDM (amil) dengan mengajukan pertanyaan pada kuisioner.Setiap item diukur dengan menggunakan skala linkert mulai dari 5 sangat setuju dan 1 sangat tidak setuju. 


\subsection{Teknik Pengumpulan Data}

Data primer dalam penelitian ini diambil menggunakan kuisioner.Kuisioner diberikan kepada amil pada Lembaga Pengelola dana zakat dimana menggunakan teknik Simpel random sampling. Sedangkan, data sekunder dalam penelitian ini kumpulkan dari buku,artikel,jurnal,internet yang berkaitan dengan masalah penelitian.

\subsection{Teknik Analisis Data}

Analisis data dilakukan dengan alat SPSS dengan terlebih dahulu melakukan uji terhadapnya:

\section{Uji Validitas}

Uji yang digunakan untuk menentukan valid tidaknya sebuah kuisioner. Dalam penelitian dikatakan valid dan mempunyai validitas tinggi apabila sebuah alat ukur tersebut dapat mengukur apa yang akan diukur

\section{Uji Reabilitas}

Diperlukan dalam penelitian karena menunjukan ketepatan dan kemantapan dalam mengukur dan menggali informasi yang diperlukan.

\section{Uji Asumsi Klasik}

Uji Asumsi klasik ialah uji yang dilakukan sebelum uji regresi linier berganda.Uji asumsi yang digunakan dalam penelitian ini ialah uji normalitas,mulitikolinieritas,heterokedastisitas, dan uji autokolerasi.

\section{Uji Regeresi linier berganda}

Untuk menguji pengaruh dua atau lebih variabel bebas ( independen) terhadap satu variabel terikat ( dependen).Metode ini mengasumsikan adanya satu garis kurus atau linier antara variabel bebas dengan para prediktornya. Dalam regresi linier berganda menggunakan rumus:

$$
\begin{aligned}
\mathrm{Y}=\mathrm{a} & +\beta 1 \mathrm{SAZ}+\beta 2 \mathrm{SC}+\beta 3 \mathrm{TR}+\beta 4 \mathrm{KA}+\epsilon \\
& \text { Keterangan: } \\
& \beta 1-\beta 4=\text { Koefisien Regresi dan estimator dari parameter } \\
\mathrm{SA} & =\text { Standar Akuntansi Zakat } \\
\mathrm{SC} & =\text { Shariah Compliance } \\
\mathrm{TR} & =\text { Transparansi } \\
\mathrm{KA} & =\text { Kompetensi SDM (Amil) } \\
\epsilon \quad & =\text { Variabel Pengganggu (Janie, 2012) }
\end{aligned}
$$

\section{Hasil Dan Pembahasan}

\subsection{Gambaran Umum}

Penelitian ini di dilakukan pada tanggal 12 sampai 20 november 2020 di lima lembaga yaitu Baznas,Laziz NU,Laziz MU,Laziz Al-ikhsan dan BBI.Dengane menyebar sebanyak 41 kuisioner dan yang kembali dan dapat diolah sebanyak 36 buah kuisioner. 


\subsection{Pengujian Hipotesis}

\section{Hasil pengujian Regresi Linier Berganda}

Tabel 1. Hasil pengujian Regresi Linier Berganda

\begin{tabular}{|c|c|c|c|c|c|}
\hline \multirow[t]{2}{*}{ Model } & \multicolumn{2}{|c|}{$\begin{array}{l}\text { Unstandardized } \\
\text { Coefficients }\end{array}$} & \multirow{2}{*}{$\begin{array}{c}\begin{array}{c}\text { Standardized } \\
\text { Coefficients }\end{array} \\
\text { Beta }\end{array}$} & \multirow[t]{2}{*}{$\mathrm{T}$} & \multirow[t]{2}{*}{ Sig. } \\
\hline & B & Std. Error & & & \\
\hline (Constant) & .309 & 1.431 & & .216 & .830 \\
\hline PSAK 109 & .189 & .028 & .425 & 6.675 & .000 \\
\hline $\begin{array}{l}\text { Shariah } \\
\text { Compliance }\end{array}$ & .349 & .142 & .188 & 2.458 & .020 \\
\hline Transparansi & .286 & .085 & .216 & 3.366 & .002 \\
\hline Kompetensi SDM & .488 & .146 & .246 & 3.336 & .002 \\
\hline
\end{tabular}

Berdasarkan tabel diatas dapat diperoleh nilai regresi linier berganda dengan menggunakan rumus:

$$
\begin{aligned}
& \mathrm{Y}=\mathrm{a}+\beta 1 \mathrm{SAZ}+\beta 2 \mathrm{SC}+\beta 3 \mathrm{TR}+\beta 4 \mathrm{KA}+\epsilon \\
& \mathrm{Y}=0,309+0,189 \mathrm{AZ}+0,349 \mathrm{SC}+0,286 \mathrm{TR}+0,488 \mathrm{KA}+\epsilon
\end{aligned}
$$

Interpretasi dari hasil regresi ialah sebagai berikut:

1. Konstanta (a)

Nilai konstanta dari persamaan diatas ialah sebesar 0,309 hal ini berarti bahwa jika variabel independen diasumsikan bernilai nol (0) maka nilai variabel dependen (beta) sebesar 0,309.

2. Akuntansi Zakat (X1) terhadap pengelolaan dana zakat (Y)

Nilai koefisien akuntansi zakat (X1) ialah sebesar 0,189 atau sebesar 18,9\% .Hal ini berarti bahwa setiap kenaikan akuntansi zakat sebesar $1 \%$ maka akan menaikan kualitas pengelolaan dana zakat sebesar 0,189 atau 18,9\%.

3. Shariah Compliance (X2) terhadap pengelolaan dana zakat (Y)

Nilai koefisien Shariah Compliance (X2) ialah sebesar 0,349 atau 34,9\% sebesar .Hal ini berarti bahwa setiap kenaikan shariah compliance sebesar $1 \%$ maka akan menaikan kualitas pengelolaan dana zakat sebesar 0,349 atau $34,9 \%$.

4. Transparansi (X3) terhadap pengelolaan dana zakat (Y)

Nilai koefisien Transparansi (X3) ialah sebesar 0,286 atau 28,6\% sebesar .Hal ini berarti bahwa setiap kenaikan Transparansi sebesar $1 \%$ maka akan menaikan kualitas pengelolaan dana zakat sebesar 0,286 atau $28,6 \%$.

5. Kompetensi sumber daya manusia (Amil) terhadap pengelolaan dana zakat (Y)

Nilai koefisien Kompetensi SDM (X4) ialah sebesar 0,488 atau 48,8\% sebesar .Hal ini berarti bahwa setiap kenaikaan komepetensi SDM sebesar $1 \%$ maka akan menaikan kualitas pengelolaan dana zakat sebesar 0,488 atau $48,8 \%$.

\section{Uji T}

1. Nilai signifikan sebesar 0,000 dimana model memiliki nilai sig < level of signifikasi $(a=0,05)$ maka hipotesis nol ditolak yang berarti faktor Akuntansi Zakat (PSAK 109) berpengaruh positif dan signifikan terhadap pengelolaan dana zakat di Kabupaten Pemalang.

2. Nilai signifikan sebesar 0,020 dimana model memiliki nilai sig < level of signifikasi $(a=0,05)$ maka hipotesis nol ditolak yang berarti faktor Shariah Compliance berpengaruh positif dan signifikan terhadap pengelolaan dana zakat di Kabupaten Pemalang.

3. Nilai signifikan sebesar 0,002 dimana model memiliki nilai sig < level of signifikasi $(a=0,05)$ maka hipotesis nol ditolak yang berarti faktor Transparansi berpengaruh positif dan signifikan terhadap pengelolaan dana zakat di Kabupaten Pemalang. 
4. Nilai signifikan sebesar 0,002 dimana model memiliki nilai sig < level of signifikasi $(a=0,05)$ maka hipotesis nol ditolak yang berarti faktor Kompetensi sumber daya manusia (Amil) berpengaruh positif dan signifikan terhadap pengelolaan dana zakat di Kabupaten Pemalang.

Uji F

Tabel 2. Uji F

\begin{tabular}{llllcc}
\hline \multicolumn{1}{c}{ Model } & Sum of Squares & Df & Mean Square & F & Sig. \\
\hline Regression & 917.085 & 4 & 229.271 & 175.617 & $.000^{\mathrm{b}}$ \\
Residual & 40.471 & 31 & 1.306 & & \\
Total & 957.556 & 35 & & & \\
\hline
\end{tabular}

Nilai probabilitas (Sig.) sebesar 0.000 yang artinya lebih kecil dari probabilitas 0,05 atau $(0,000<0,05)$ dan dapat disimpulkan bahwa Ha diterima yang artinya model yang dibuat sudah benar.Yang dapat diartikan bahwa akuntansi zakat, shariah compliance,transparansi dan kompetensi SDM berpengaruh secara simultan terhadap pengelolaan dana zakat.

\section{Uji Determinasi}

Tabel 3. Uji Determinasi

\begin{tabular}{rlll}
\hline $\mathrm{R}$ & $\mathrm{R}$ Square & Adjusted R Square & Std. Error of the Estimate \\
\hline $.979^{\mathrm{a}}$ & .958 & .952 & 1.14259 \\
\hline
\end{tabular}

Dilihat dari tabel model summary diatas menunjukan dari Adjusted $R$ Square sebesar 0,952 yang berarti dapat ditarik kesimpulan bahwa Akuntansi Zakat,shariah compliance,transparansi dan kompetensi sumber daya manusia (Amil) bersama - sama berpengaruh sebesar 95,2\% terhadap pengelolaan dana zakat sedangkan $4.8 \%$ adalah pengaruh variabel lain yang tidak diteliti.

\section{Penutup}

\subsection{Kesimpulan}

1. Dari hasil uji parsial bahwa tingkat signifikan sebesar 0,000 yaitu lebih kecil dari 0,05 yang berarti $\mathrm{H}_{0}$ ditolak dan $\mathrm{H}_{1}$ diterima. Jadi variabel akuantansi zakat (psak 109) berpengaruh positif dan signifikan terhadap pengelolaan dana zakat di Kabupaten Pemalang.

2. Dari hasil uji parsial bahwa tingkat signifikan sebesar 0,020 yaitu lebih kecil dari 0,05 yang berarti $\mathrm{H}_{0}$ ditolak dan $\mathrm{H}_{2}$ diterima.Jadi variabel Shariah Compliance berpengaruh positif dan signifikan terhadap pengelolaan dana zakat di Kabupaten Pemalang.

3. Dari hasil uji parsial bahwa tingkat signifikan sebesar 0,002 yaitu lebih kecil dari 0,05 yang berarti $\mathrm{H}_{0}$ ditolak dan $\mathrm{H}_{3}$ diterima.Jadi variabel Transparansi berpengaruh positif dan signifikan terhadap pengelolaan dana zakat di Kabupaten Pemalang.

4. Dari hasil uji parsial bahwa tingkat signifikan sebesar 0,002 yaitu lebih kecil dari 0,05 yang berarti $\mathrm{H}_{0}$ ditolak dan $\mathrm{H}_{4}$ diterima.Jadi variabel kompetensi sumber daya manusia (amil) berpengaruh positif dan signifikan terhadap pengelolaan dana zakat di Kabupaten Pemalang.

5. Hasil $\mathrm{R}$ Square $\left(\mathrm{R}^{2}\right)$ sebesar 0,952,menunjukan bahwa kontribusi seluruh variabel independen dalam menjelaskan variabel dependen adalah $95,2 \%$ sedangkan sisanya $4.8 \%$ dipengaruhi variabel lain yang tidak dimasukan dalam model penelitian ini.

\subsection{Keterbatasan}

1. Masih terbatas dalam pengembangan variabel,dalam penelitian ini hanya menggunakan empat variabel yaitu akuntansi zakat (psak 109), shariah compliance, transparansi dan kompetensi sumber daya manusia ( amil ) sehingga kemungkinan masih terdapat varibel lain yang masih perlu diteliti terhadap pengelolaan dana zakat

2. Penelitian ini hanya menggunakan kuisioner sebagai instrumen penelitian,yang kemungkinan terjadi bias,karena bisa terjadi dalam pengisian responden tidak benar-benar diisi oleh responden yang bersangkutan. 
3. Penelitian terbatas hanya pada wilayah Kabupaten Pemalang saja.Sehingga hasil tersebut tidak bisa mejadi acuan atau di generalisasikan kepada lembaga zakat diwilayah lain.

\subsection{Saran}

1. Untuk penelitian selanjutnya diharapkan melakukan penelitian lebih lanjut mengenai faktorfaktor yang mempengaruhi pengelolaan dana zakat di lembaga pengelolaan dana zakat

2. Perluasan wilayah bukan hanya terbatas pada satu wilayah,karna biasanya pada daerah yang masih lingkup kecil seperti Kabupaten Pemalang masih minim sumber daya manusia (amil) pada lembaga pengelola zakat

3. Untuk penelitian selanjutnya diharapkan dalam pengisian kuisioner sebaiknya responden didampingi langsung dalam pingisian oleh peniliti agar informasi yang diperoleh lebih tepat.

4. Bagi lembaga zakat terkait diharapkan untuk kedepannya melakukan pelatihan mengenai akuntansi zakat untuk meningkatkan kulaitas pengelolaa dana zakat

5. Lembaga pengelola zakat sebaiknya meningkatkan sosialisasi dan transparansi kepada masyarakat khususnya dipedesaan, untuk meningkatkan penerimaan zakat.

\section{Daftar Pustaka}

Afendi, A. (2018). Pengaruh Variabel Makroekonomi Terhadap Jumlah Penerimaan Zakat di Badan Amil Zakat Nasional (Baznas) Pusat Tahun 2012-2016. Muqtasid: Jurnal Ekonomi Dan Perbankan Syariah, 9(1), 54-69.

Aprilia, L. (2017). Analisis Penerapan PSAK 109 Pada Lembaga Amil Zakat Infaq Dan Shadaqah (LAZIZ).

Apriliani, E. (2017). Pengaruh Kompetensi SDM, Penerapan PSAK 109, Pengendalian Internal, Pemanfaatan Teknologi Informasi Dan Employee Engagement Terhadap Kualitas Laporan Keuangan LAZ Dikota Semarang. Universitas Negeri Semarang.

Budi. (2017). Pengelolaan Zakat Oleh Badan Amil Zakat Dikabupaten Tulang Bawang” Skripsi Pengembangan Masyarakat Islam. 92. Retrieved From Pengelolaan Zakat Oleh Badan Amil Zakat Dikabupaten Tulang Bawang.

Hajar, N. I. (2017). Pengaruh Transparansi Dan Akuntabilitas Terhadap Kinerja Pengelolaan Anggaran Pada UPTD Taman Budaya Sulawesi Selatan. 11.

Hardyansyah. (2016). Pengaruh Kompetensi Sumber Daya Manusia Dan Pemanfaatan Teknologi Informasi Terhadap Kualitas Laporan Keuangan Dengan Pengendalian Intern Sebagai Variable Moderating. 27.

Islami, T. (2017). Definisi Makna Dan Pengertian Syariah. Retrieved July 5, 2020, from https://www.tongkronganislami.net

Janie, D. N. A. (2012). Statistik Deskriptif \& Regresi Linier Berganda Dengan SPSS. Jurnal, April, 13file:///C:/Users/Acer/Downloads/scholar (3).risf.

JavanLabs. (2020). Suratval-Baqarah Ayat 43. Retrieved from https://tafsirq.com/2-al-baqarah/ayat-43

Lusi, F., \& Usnan, S. E. I. (2017a). Pengaruh Shariah Compliance, Transparansi, Akuntabilitas dan Kompetensi Sumber Daya Manusia (SDM) Terhadap Pengelolaan Dana Zakat. Studi Pada Organisasi Pengelola Zakat di Kabupaten Sukoharjo (pp. 33-34). pp. 33-34.

Lusi, F., \& Usnan, S. E. I. (2017b). Pengaruh Shariah Compliance, Transparansi, Akuntabilitas dan Kompetensi Sumber Daya Manusia (SDM) Terhadap Pengelolaan Dana Zakat. Studi Pada Organisasi Pengelola Zakat di Kabupaten Sukoharjo (pp. 23-24). pp. 23-24. IAIN Surakarta.

Nasim, A., \& Romdhon, M. R. S. (2014). Pengaruh Transparansi Laporan Keuangan, Pengelolaan Zakat, dan Sikap Pengelola Terhadap Tingkat Kepercayaan Muzakki. Jurnal Riset Keuangan Dan Akuntansi, IIfile:/I/, 551.

Potensi Zakat Kabupaten Pemalang Sangat Besar 2. (2015). Retrieved from https://pemalang.kemenag.go.id

Rosa, E. M. (2018). Kepatuhan (Compliance). Retrieved July 22, 2020, from https://mars.umy.ac.id Sanjaya, I , K, A. (2019). Pengaruh Shariah Compliance (Kepatuhan Syariah), Transparansi, Akuntabilitas, Kompetensi Sumber Daya Manusia (SDM) dan Pengendalian Internal Terhadap 
Pengelolaan Dana Zakat (Di Kota Pekanbaru) (p. 24file:///C:/Users/Acer/Downloads/scholar (6).ris). p. 24file:///C:/Users/Acer/Downloads/scholar (6).ris. UNIVERSITAS ISLAM NEGERI SULTAN SYARIF KASIM RIAU.

Sari, D. P. (2019). Pengaruh Penerapan Standar Akuntansi Zakat, Transparansi Dan Sistem Pengendalian Intern Terhadap Akuntabilitas Keuangan (Studi Empiris Pada Badan Amil Zakat Nasional Di Pekanbaru) (Doctoral Dissertation, Universitas Sultan Syarif Kasim Riau). UNIVERSITAS SULTAN SYARIF KASIM RIAU.

Umah, U. K. (2011). Penerapan Akuntansi Zakat Pada Lembaga Amil Zakat (Studi Pada Laz DPU DT Cabang Semarang). Value Added| Majalah Ekonomi Dan Bisnis, 7(2), 78-79.

Wijayanti, R., \& Handayani, N. (2017). Pengaruh Kompetensi SDM dan Implementasi Akuntansi Akrual Terhadap Kualitas Laporan Keuangan Daerah. Jurnal Ilmu Dan Riset Akuntansi (JIRA), 6(3), 1292. 